\title{
Editorial
}

\section{Un cerebro prestado}

Día tras día, en esas jornadas calurosas que han dado vida a este último verano, observaba durante minutos, agazapado, fuera del alcance de su vista para no turbarlo, a un anciano que vivía en el pequeño pueblo que compartíamos, unas casas más arriba, al que saludaba cortésmente cuando llegaba a su altura y del que obtenía siempre una respuesta amable y automática, sin otro deseo, a mi ver, que el de no ser molestado en su debate interior. Cada jornada me preguntaba lo mismo: en qué podía estar pensando durante esas largas horas de manifiesta soledad, con la única ocupación aparente de buscarle la vuelta al sol. La cara tallada por el cincel del tiempo, casi inmutable.

Traté durante esas jornadas de distancia amistosa de imaginar, de jugar a interpretar su realidad con cada arqueo de cejas. A buen seguro, si alguien me hubiera sorprendido en esta actitud voyeurista se hubiera preguntado, no sin parte de razón, por el propósito de esa dilatada vigilancia. Algo a lo que no hubiera podido responder con un argumento cré́ble. Se trataba, sin duda, de un entretenimiento trenzado por la actualidad más reciente, mi vocación gerontológica y que trataba de confitar dentro de un cerebro prestado. Quizás el ejercicio de esos días no fuera otro más que el de visualizar mis personales preocupaciones si habitara en un cuerpo más viejo. Uno como aquel que servía de modelo, a la sombra de su casa, en el poyo que prolongaba su portal con la angosta calle y que ocupaba casi de sol a sol.

Creí ver en su rostro hastiado un gesto de resignación, sin estridencias, y pensé que esa soledad serena tendría que ver quizás con un sentimiento de misión cumplida y un deseo creciente de volver a reencontrarse con aquellos seres queridos, que hace años ya no están.

Otra mirada cruzada la adjudiqué a una reflexión desde ese asiento a la marcha de la economía de nuestro país. Creí entrever que se preguntaba sobre cómo una sociedad que en tan poco tiempo ha logrado cotas impensables de bienestar no va a soportar esta contrariedad. Pero, por otra parte, se debatía viendo que el paro atenaza ya a varios de sus familiares, quienes precisamente no están jubilosos y sus caracteres comienzan a agriarse. A veces me parece leer en ellos acusaciones hacia los improductivos, hacia los mayores, hacia las pensiones... Seguro que son imaginaciones mías pero no me gustaría que esto se prolongara, no tengo buenas vibraciones y no querría descubrir cómo se alimenta por ello el despreciable maltrato.

Mi imaginación no pudo dejar de vislumbrar en otra sesión una mirada de ese veterano hacia la salud y, especialmente, desde su umbral de fragilidad, a esa alarmante epidemia de gripe A que ha perdonado hasta la fecha a los viejos, pero... ¿qué pasará en otoño? ¿Seguro que esta cepa de inhabitual virulencia dejará de lado el pasto más abonado, nosotros, todos "tocados" por uno u otro proceso? Si cada año las despedidas de este mundo de muchos de mis contemporáneos se sirve como detonante de la gripe estacional, ¿cómo no se van a fijar estos ávidos gérmenes en esos cuerpos de guardia relajada? Por si acaso, prepararé mi equipaje, el aviso de partida puede ser inmediato y los ilusos pueden ser sorprendidos.

Fueron muchas las singulares y seguro equívocas adivinaciones en las que me entretuve en esos días, pero no puedo dejar de relatar lo que, con seguridad, vi dibujarse en otra de esas exploraciones. Su pen- 
103 samiento estaba puesto ahora en el sentimiento de utilidad o inutilidad, en la capacidad de poder seguir viviendo con mínima dignidad sin necesitar de alguien permanentemente y hasta para las cosas más íntimas. Definitivamente, creí adivinar que con inusual rotundidad, se negaba a seguir viviendo si esa situación llegara. No quiero que el recuerdo que permanezca sea el de un estorbo inanimado que roba la vida de los que han decidido o les han impuesto el cuidar de mí. Alguien habla de esa nueva ley que ayudará a que esas situaciones no sean tan complejas, pero ¿creen que tendrá tanto carácter como para revalidar el noble compromiso de las familias de cuidar sin morir en el intento? De verdad, yo no querría ser testigo callado de las diatribas sobre si mi futuro es posible fijarlo aquí, en mi casa, o que los míos planteen la opción de terminar mis días en una impersonal residencia. Con cierta ligereza he visto cómo se ha blandido con otros de mis conocidos, con familia, y de esas que parecían buenas. Tampoco quiero enterrar en vida a esta hija que bastante hace para seguir cuidándome y atender al resto, pero no quiero terminar esta vida al sol, entre desconocidos, porque alguien me dejó ahí hace horas y no soy capaz de mover ese sillón salvo con el pensamiento. No quiero y pido a Dios que me lleve cuando no me valga como hasta ahora o bien que esa Ley de Ayuda, pueda, gracias a la bondad de todos los implicados, facilitar una andadura digna en esa última parada, donde las energías para gobernarme y cambiar mi rumbo apenas existen y donde la sobrecarga de los cuidadores que han decidido intentarlo es de enorme altura.

Pido ahora excusas a este hombre mayor que durante algunos días prestó su asiento a mi pensamiento, para retratar desde su retina una mínima parte de mis actuales y futuras preocupaciones. Pero sólo ha sido un frívolo juego estival, a buen seguro alejado de los sensatos y documentados juicios que debieran figurar en esta tribuna científica. También mis excusas a los lectores por este desliz veraniego.

J. Javier Soldevilla Agreda Director de Gerokomos 